\title{
Enterobacter oryzae sp. nov., a nitrogen-fixing bacterium isolated from the wild rice species Oryza latifolia
}

\author{
Guixiang Peng, ${ }^{1}$ Wu Zhang, ${ }^{2}$ Huifen Luo, ${ }^{2}$ Hongwei Xie, ${ }^{1}$ Weihao Lai ${ }^{2}$ \\ and Zhiyuan $\operatorname{Tan}^{2}$ \\ ${ }^{1}$ College of Resources and Environment, South China Agricultural University, Guangzhou 510642, \\ PR China
${ }^{2}$ Provincial Key Lab of Plant Molecular Breeding, College of Agriculture, South China Agricultural University, Guangzhou 510642, PR China

Correspondence

Zhiyuan Tan

zytan@scau.edu.cn

\begin{abstract}
Twelve facultatively anaerobic, endophytic diazotrophs were isolated from surface-sterilized roots of the wild rice species Oryza latifolia and characterized by phenotypic and molecular methods. Six isolates were grouped together as group A by phenotypic characters, and this grouping was confirmed by SDS-PAGE whole-cell protein patterns and insertion sequence-based PCR (ISPCR) methods. Phylogenetic analysis of the $16 \mathrm{~S}$ rRNA gene sequence indicated that group A, represented by strain Ola $51^{\top}$, is closely related to Enterobacter radicincitans $\mathrm{D} 5 / 23^{\top}(98.9 \%$ similarity, except that $E$. radicincitans $\mathrm{D} 5 / 23^{\top}$ has a $70 \mathrm{bp}$ insertion) and Enterobacter cloacae (98.0\% similarity to the type strain). rpoB gene sequence analysis also showed strain Ola $51^{\top}$ has the highest sequence similarity to E. radicincitans DSM $16656^{\top}(98.3 \%)$, but supported the distinct position. Biological and biochemical tests, protein patterns, genomic DNA fingerprinting, antibiotic resistance and comparison of cellular fatty acids showed differences among group $A, E$. radicincitans DSM $16656^{\top}$ and E. cloacae ATCC $13047^{\top}$. DNA-DNA hybridization distinguished strain Ola $51^{\top}$ from closely phylogenetically related Enterobacter species. Based on these data, the novel species Enterobacter oryzae sp. nov. is proposed, with strain Ola $51^{\top}$ (=LMG $24251^{\top}$ $=$ CGMCC $1.7012^{\top}$ ) as the type strain.
\end{abstract}

The wild rice species Oryza latifolia belongs to the Oryza officinalis complex, which is the largest in the genus Oryza. $O$. latifolia, O. alta and O. grandiglumis are three closely related tetraploid species. O. latifolia is widely distributed in Central and South America and on the Caribbean islands (Vaughan, 1989). Endophytic diazotrophic bacteria, known to supply biologically fixed nitrogen directly to these nonlegume plants, may have great potential to improve sustainable rice production (Chaintreuil et al., 2000).

Diazotrophic bacteria belonging to the species Enterobacter cloacae and Klebsiella oxytoca and the genera Alcaligenes

The GenBank/EMBL/DDBJ accession numbers for the partial $16 \mathrm{~S}$ rRNA gene sequences of strains Ola 50 , Ola $51^{\top}$ and $\mathrm{Ola} 01$ are respectively EF488758-EF488760 and the accession number for the partial rpoB gene sequence of strain Ola $51^{\top}$ is EU249553.

A comparison of the biological and biochemical characteristics of strain Ola $51^{\top}$ with those of related strains, detailed DNA-DNA hybridization results, a transmission electron micrograph of cells of strain Ola $51^{\top}$, comparisons of IS-PCR and whole-cell protein SDS-PAGE profiles of selected novel strains and related strains and an $r p o B$ gene sequencebased neighbour-joining tree are available as supplementary material with the online version of this paper. and Azospirillum have previously been isolated from the rhizosphere of wetland rice (Baldani \& Doebereiner, 1980; Fujie et al., 1987; Tou \& Zhou, 1989). A number of diazotrophic bacteria, including strains of Herbaspirillum rubrisubalbicans (from Oryza barthii), Herbaspirillum seropedicae (O. officinalis, O. rufipogon), Ideonella dechloratans (O. sativa), Enterobacter cancerogenus (O. rufipogon), Azospirillum lipoferum (O. grandiglumis, O. sativa) and Azospirillum brasilense (O. rufipogon), were isolated from stems of wild rice species by Elbeltagy et al. (2001). In addition to these diazotrophs isolated from rice, a remarkable diversity of uncultured diazotrophs has also been detected in association with rice roots (Engelhard et al., 2000; Hurek et al., 2002; Tan et al., 2001; Ueda et al., 1995). These diazotrophic isolates from wild rice may serve as valuable bioresource micro-organisms that could potentially supply nitrogen to rice and promote rice growth. Little work has been reported on nitrogen-fixing isolates from the wild rice species O. latifolia.

Samples of O. latifolia were collected from the Wild Rice Core Collection Nursery at South China Agricultural University. Procedures for sterilization of rice roots and 
isolation and purification of nitrogen-fixing bacteria on VM medium (Reinhold-Hurek et al., 1993) were described previously (Peng et al., 2006). The nitrogen-fixing ability of all isolates was checked by using the acetylene-reduction assay as described by Eckert et al. (2001) and confirmed by PCR amplification of the nifH gene (Peng et al. 2006), which codes for the nitrogenase reductase enzyme involved in nitrogen fixation. The primers and the protocol for nifH gene amplification were described by Peng et al. (2006). A total of 12 putatively endophytic nitrogen-fixing bacteria (isolates Ola 01 , Ola 05 , Ola 08 , Ola 10 , Ola 12 , Ola 15 , Ola 28 , Ola 32, Ola 37, Ola 46, Ola50 and Ola 51) were isolated from root samples of $O$. latifolia. These isolates were obtained with VM medium supplied with DL-malic acid as the sole carbon source. All of them were Gram-negative, facultatively anaerobic, motile, straight or curved rods. Acetylene reduction was detected in all the isolates within $20 \mathrm{~h}$ of acetylene injection. All strains were able to reduce acetylene to ethylene in the range of 60-115 nmol ethylene $\mathrm{h}^{-1}$ per $10^{8}$ cells at $28{ }^{\circ} \mathrm{C}$ without addition of yeast extract. Following PCR amplification of the nifH gene, the expected fragment of about $360 \mathrm{bp}$ was obtained from all the isolates and the positive-control strain A. brasilense $\mathrm{Sp} 7^{\mathrm{T}}$, which further confirmed the nitrogen-fixing capacity of these isolates.

The phenotypic features described previously (Chen et al., 1988; Gao et al., 1994) were used to group the isolates. Phenotypic analyses covered utilization of sugars, amino acids, alcohols and organic acids as sole carbon sources, resistance to various antibiotics (Tan et al., 1999), ranges of $\mathrm{NaCl}$ concentration and $\mathrm{pH}$ for growth and biochemical characteristics tested by using the API 20E kit (bioMérieux). The results were converted into a binary matrix. Phenotypic similarity (simple matching coefficient; $S_{\mathrm{SM}}$ ) between each pair of strains was estimated and used in clustering analysis to produce a dendrogram using the unweighted pair group method with arithmetic means (UPGMA) as described by Sneath \& Sokal (1973). The 12 diazotrophic isolates were separated into three groups at a similarity of $76 \%$ (Fig. 1). Group A included six strains, Ola 01 , Ola 10 , Ola 12 , Ola 28 , Ola 50 and Ola $51^{\mathrm{T}}$, group B comprised strains Ola 05 and Ola 37 and strains Ola 08, Ola 15 and Ola 46 belonged to group C. One diazotrophic isolate, Ola 32, could not be included in any cluster. $16 \mathrm{~S}$ rRNA gene sequences of about $900 \mathrm{bp}$ were obtained from representative strains from each group (Ola $51^{\mathrm{T}}$, Ola 05 , Ola 46 and Ola 32). Similarities over this partial sequence between the strain pairs Ola 05 (group B) and Pantoea agglomerans DSM $3493^{\mathrm{T}}$ (GenBank accession no. AJ233423), Ola 46 (group C) and Pseudomonas putida ATCC 17485 (AF094739) and Ola 32 and Azospirillum brasilense ATCC $29145^{\mathrm{T}}$ (AY324110) were more than $99 \%$. Strain Ola $51^{\mathrm{T}}$ of group A shared $96.8 \%$ sequence similarity (over $900 \mathrm{bp}$ ) with Enterobacter cloacae ATCC $13047^{\mathrm{T}}$ (GenBank accession no. AJ251469) and Enterobacter radicincitans $\mathrm{D} 5 / 23^{\mathrm{T}}$ (AY563134), although the sequence of $E$. radicincitans $\mathrm{D} 5 / 23^{\mathrm{T}}$ has a $70 \mathrm{bp}$

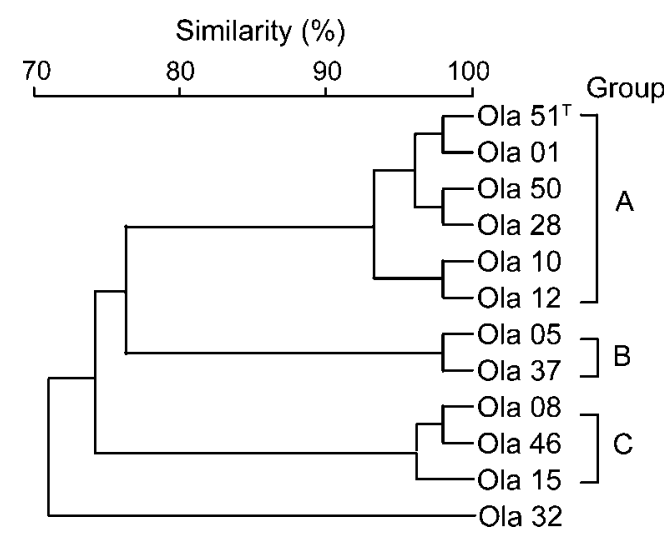

Fig. 1. Dendrogram showing phenotypic similarities among the diazotrophic isolates from O. latifolia. The UPGMA method was used for cluster analysis (Sneath \& Sokal, 1973).

insertion. The biological and biochemical characters and antibiotic resistance of E. radicincitans DSM $16656^{\mathrm{T}}$ and $E$. cloacae ATCC $13047^{\mathrm{T}}$ were also tested and compared with those of the representative strain Ola $51^{\mathrm{T}}$ of group A (Supplementary Table S1, available in IJSEM Online).

Negatively stained cells (Cole \& Popkin, 1981) from cultures growing in liquid medium were used for the examination of flagella under a transmission electron microscope. Cell morphology was observed by light microscopy and transmission electron microscopy (Hitachi 600). Cells of strain Ola $51^{\mathrm{T}}$ are straight or slightly curved rods, $0.8-1.1 \times 1.4-2.0 \mu \mathrm{m}$, with subpolar flagella (Supplementary Fig. S1 in IJSEM Online).

IS-PCR (insertion sequence-based PCR) fingerprinting was performed to evaluate the genotypic diversity of the isolates. The conditions of PCR amplification and electrophoresis were described previously (Peng et al., 2006). The amplified fragments were between 100 and $600 \mathrm{bp}$ long. The six diazotrophic isolates of group A showed very similar patterns (total six fragments, five common fragments), but these patterns differed from those of Enterobacter aerogenes ATCC $13048^{\mathrm{T}}$, E. cloacae ATCC $13047^{\mathrm{T}}$ and E. radicincitans DSM $16656^{\mathrm{T}}$ (Supplementary Fig. S2).

Methods of cell preparation and protein extraction and analysis of whole-cell protein SDS-PAGE patterns were described previously (Tan et al., 2001). The six diazotrophic isolates had identical protein patterns in the range 14-116 kDa. The main intense protein bands differed between the six novel isolates and the reference strains $E$. cloacae ATCC $13047^{\mathrm{T}}$ and E. aerogenes ATCC $13048^{\mathrm{T}}$ (Supplementary Fig. S3).

Harvesting of cells and extraction of fatty acids were performed as described by Sasser (1990). Fatty acid analysis methods were described by Peng et al. (2006). The cellular fatty acid profiles of strain Ola $51^{\mathrm{T}}$, representing the 
diazotrophs of group A, and the related strains $E$. radicincitans DSM $16656^{\mathrm{T}}$ and E. cloacae ATCC $13407^{\mathrm{T}}$ had 11 components in common, at retention times of 6.2 , $8.8,12.0,12.5,14.5,16.5,17.5,18.4,19.5,22.6$ and $25.6 \mathrm{~min}$. These common components respectively made up 81.2, 97.3 and $98.6 \%$ of the components detected in Ola $51^{\mathrm{T}}$, E. radicincitans DSM $16656^{\mathrm{T}}$ and E. cloacae ATCC $13407^{\mathrm{T}}$ (Supplementary Table S2). Strain Ola 51 had five components, at retention times of 9.5, 10.5, 13.4, 15.8 and $21.2 \mathrm{~min}$, which were absent or trace peaks (less than $2 \%$ ) in the profiles of E. radicincitans DSM $16656^{\mathrm{T}}$ and $E$. cloacae ATCC $13407^{\mathrm{T}}$. The relative abundance of each compound was also different among the three strains.

The partial 16S rRNA gene sequences of representative isolates, together with some closely related sequences from GenBank of strains of species with validly published names, were aligned by using the CLUSTAL w program package (Thompson et al., 1994) and the alignment was adjusted manually using GeneDoc (Nicholas \& Nicholas, 1997). Ambiguous bases were excluded from the calculation of similarity. The tree topology was inferred by the neighbour-joining method (Saitou \& Nei, 1987) and the phylogenetic tree was visualized and bootstrapped by using the TREECON software package (Van de Peer \& De Wachter, 1994). Three strains from group A, Ola 01, Ola 50 and Ola $51^{\mathrm{T}}$, were sequenced, and they shared more than $99.8 \%$ $16 \mathrm{~S}$ rRNA gene sequence similarity. In the reconstructed phylogenetic tree (Fig. 2), these three strains formed a monophyletic group within the genus Enterobacter and were related more closely to E. radicincitans $\mathrm{D} 5 / 23^{\mathrm{T}}$ (98.9\% similarity over $1481 \mathrm{bp}$ ) than to other species. Bootstrap confidence also indicated that strain Ola $51^{\mathrm{T}}$ and E. radicincitans $\mathrm{D} 5 / 23^{\mathrm{T}}$ formed a phylogenetic group (with a bootstrap value of $100 \%$ ).

DNA-DNA relatedness was determined by the initial renaturation rate method (De Ley et al., 1970) in $2 \times$ SSC with three repetitions and mean values were calculated. DNA was isolated and purified as described by Marmur (1961) and DNA base composition was determined spectrophotometrically. DNA from Escherichia coli K-12 was used

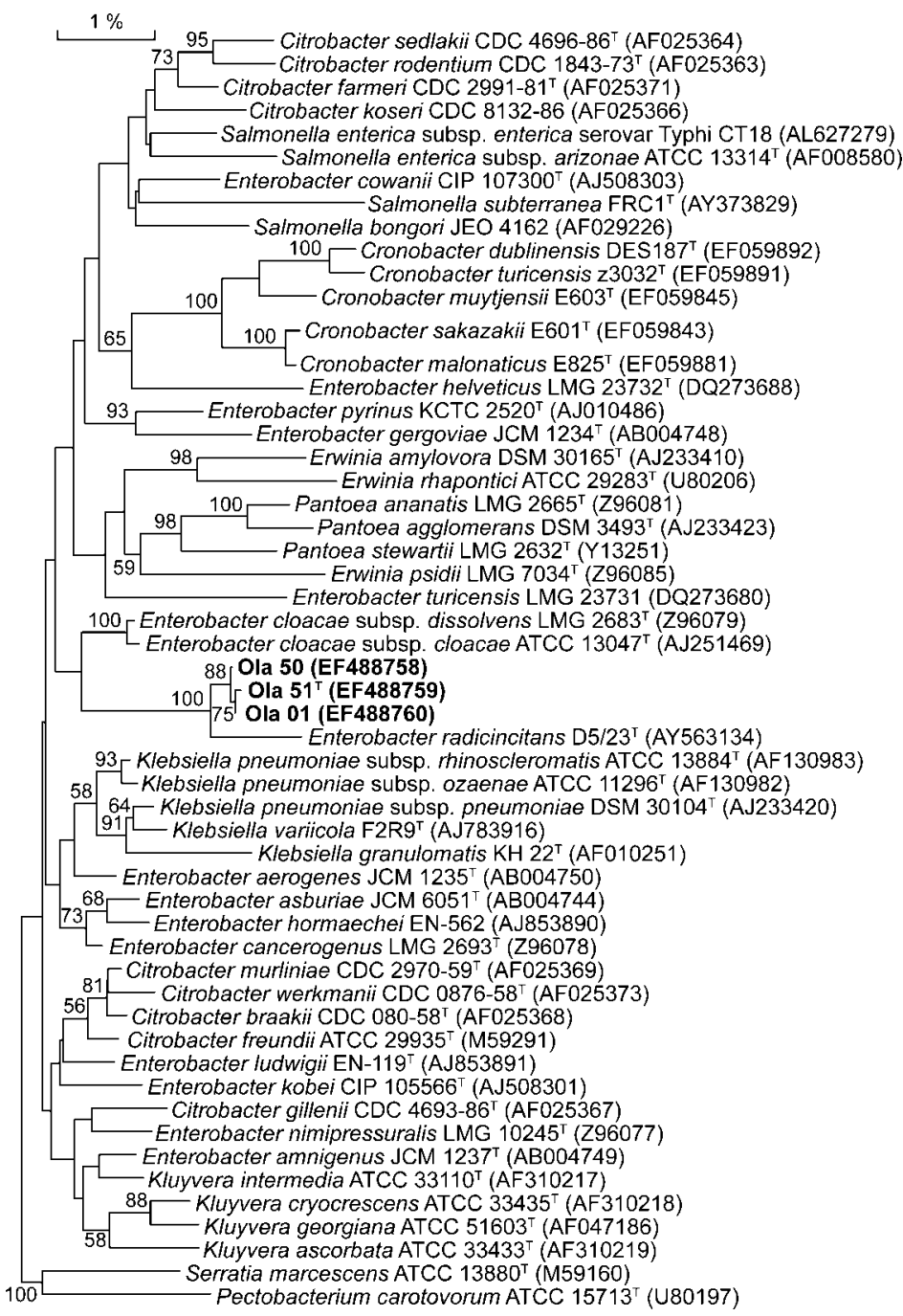

Fig. 2. Phylogenetic tree constructed by neighbour-joining analysis of 16S rRNA gene sequences showing that strain Ola $51^{\top}$ is most closely related to $E$. radicincitans $\mathrm{D} 5 / 23^{\top}$. Numbers at nodes indicate percentages of occurrence in 1000 bootstrapped trees; only values greater than $55 \%$ are shown. Bar, $1 \%$ nucleotide substitutions. 
as the standard for estimation of $\mathrm{G}+\mathrm{C}$ content. The $\mathrm{G}+\mathrm{C}$ content of the genomic DNA of strain Ola $51^{\mathrm{T}}$ was $55.0 \pm 0.4 \mathrm{~mol} \%$. The results of DNA-DNA hybridization are presented in Supplementary Table S3. DNA-DNA relatedness among the strains of group A varied from 88 to $100 \%$, indicating that they were members of the same genomic species. DNA-DNA relatedness among E. radicincitans DSM $16656^{\mathrm{T}}$, E. cloacae ATCC $13047^{\mathrm{T}}$ and three strains of group A was 33-43\%. Relatedness between Enterobacter asburiae JCM $6051^{\mathrm{T}}$ and three strains of group A was $28-35 \%$.

As $r p o B$ sequence analysis has been reported previously by several authors to be useful for species discrimination within the family Enterobacteriaceae (Drancourt et al., 2001; Kämpfer et al., 2005; Li et al., 2004; Mollet et al., 1997), the forward primer CM7 (5'-AACCAGTTCCGCGTTGGCCTGG-3') and reverse primer CM31b (5'-CCTGAACAACACGCTCGGA-3') (Mollet et al., 1997) were used to amplify the $r p o B$ gene from strain Ola $51^{\mathrm{T}}$. PCR fragments were sequenced directly following the protocol of Mollet et al. (1997) with the forward sequencing primer CM81 (5'-CAGTTCCGCGTTGGCCTG- $3^{\prime}$ ) and reverse primer CM32b (5'-CGGAACGGCCTGACGTTGCAT-3'). The $r p o B$ gene sequence obtained from strain Ola $51^{\mathrm{T}}$ was aligned with related sequences from GenBank, and phylogenetic analysis was performed as described above for $16 \mathrm{~S}$ rRNA gene sequence analysis. A phylogenetic tree constructed by neighbour-joining analysis is shown in Supplementary Fig. S4. The phylogenetic position of strain Ola $51^{\mathrm{T}}$ on the basis of $r p o B$ gene sequence analysis is similar to that derived from 16S rRNA gene sequence analysis. The highest $r p o B$ gene sequence similarity (following comparison of $948 \mathrm{bp}$ of the $r p o B$ gene sequence) of strain Ola $51^{\mathrm{T}}$ was found with E. radicincitans $\mathrm{D} 5 / 23^{\mathrm{T}}$ (98.2\% similarity). The similarities between strain Ola $51^{\mathrm{T}}$ and E. cloacae subsp. cloacae ATCC $13407^{\mathrm{T}}$ and $E$. cloacae subsp. dissolvens ATCC $23373^{\mathrm{T}}$ were 92.5 and $92.2 \%$. rpoB gene sequence analysis, in addition to DNADNA hybridization experiments and phenotypic characterization, indicates that strain Ola $51^{\mathrm{T}}$ represents a novel species of the genus Enterobacter.

Table 1. Phenotypic characteristics that differentiate the group A strains (Enterobacter oryzae sp. nov.) from related species of the genus Enterobacter

Taxa: 1, Enterobacter oryzae sp. nov.; 2, E. radicincitans (data from Kämpfer et al., 2005); 3, E. turicensis (Stephan et al., 2007); 4, E. helveticus (Stephan et al., 2007); 5, E. gergoviae (Farmer et al., 1985; Stephan et al., 2007); 6, E. asburiae (Brenner et al., 1986; Hoffmann et al., 2005a); 7, E. kobei (Hoffmann et al., 2005a; Kosako et al., 1996); 8, E. hormaechei (Kämpfer et al., 2005; O'Hara et al., 1989); 9, E. cancerogenus (Hoffmann et al., 2005a; Stephan et al., 2007); 10, E. pyrinus (Hoffmann et al., 2005a; Stephan et al., 2007); 11, E. ludwigii (Hoffmann et al., 2005b; Kämpfer et al., 2005); 12, E. cloacae subsp. cloacae (Hoffmann et al., 2005a; Kämpfer et al., 2005); 13, E. cloacae subsp. dissolvens (Brenner et al., 1986; Hoffmann et al., 2005a); 14, E. cloacae ATCC $13047^{\mathrm{T}}$ (data from this study). The percentage of strains giving a positive result is scored as:,$- 0-10 \% ;-/+, 10-$ $20 \%$; , 20-80\%; +/-, 80-90\%; +, 90-100\%. ND, No data available.

\begin{tabular}{|c|c|c|c|c|c|c|c|c|c|c|c|c|c|c|}
\hline Characteristic & 1 & 2 & 3 & 4 & 5 & 6 & 7 & 8 & 9 & 10 & 11 & 12 & 13 & 14 \\
\hline Motility & + & + & + & + & + & $+1-$ & $+1-$ & $+1-$ & + & + & + & + & + & + \\
\hline Arginine dihydrolase ${ }^{\star}$ & + & + & - & - & - & + & + & $\mathrm{V}$ & + & - & + & + & + & + \\
\hline Ornithine decarboxylase ${ }^{\star}$ & + & - & - & - & + & + & + & + & + & + & + & + & + & + \\
\hline Lysine decarboxylase ${ }^{\star}$ & + & - & - & - & + & - & - & - & - & + & - & - & - & - \\
\hline Methyl red test & + & $\mathrm{ND}$ & + & + & - & + & $\mathrm{ND}$ & $\mathrm{v}$ & - & $\mathrm{V}$ & $\mathrm{ND}$ & - & - & - \\
\hline \multicolumn{15}{|l|}{ Carbon source utilization: } \\
\hline Sucrose & + & + & - & - & + & + & + & + & - & + & + & + & + & + \\
\hline Citrate & + & + & - & - & + & + & + & + & + & - & + & + & + & + \\
\hline Dulcitol & + & + & + & + & - & - & $\mathrm{V}$ & + & - & - & - & - & - & - \\
\hline Putrescine & - & - & - & + & $\mathrm{V}$ & $-1+$ & $\mathrm{V}$ & - & + & + & - & + & + & + \\
\hline Mucate & + & - & + & + & - & $\mathrm{V}$ & $\mathrm{V}$ & $\mathrm{V}$ & + & - & + & $\mathrm{V}$ & + & + \\
\hline 3-Hydroxybutyrate & $+1-$ & - & $\mathrm{ND}$ & $\mathrm{ND}$ & $\mathrm{V}$ & + & $+1-$ & - & - & - & $\mathrm{V}$ & + & + & + \\
\hline Methyl $\alpha$-D-glucoside & + & - & $\mathrm{ND}$ & ND & - & + & $\mathrm{V}$ & + & - & - & + & + & + & + \\
\hline 1-O-Methyl $\alpha$-galactopyranoside & $\mathrm{ND}$ & ND & + & + & + & $+1-$ & + & - & - & - & + & + & + & ND \\
\hline 3-O-Methyl D-glucopyranoside & ND & $\mathrm{ND}$ & - & - & - & - & - & $\mathrm{v}$ & + & - & $+1-$ & - & - & ND \\
\hline
\end{tabular}

${ }^{\star}$ Determined by using the API 20E kit. 
The taxonomic relationships among genera and species within the family Enterobacteriaceae are still poorly understood and are being continually updated. For example, Enterobacter intermedius was transferred to the genus Kluyvera as Kluyvera intermedia and Kluyvera cochleae was reclassified as a later synonym of Kluyvera intermedia (Pavan et al., 2005), and the genomospecies of Enterobacter sakazakii were described as Cronobacter sakazakii, C. malonaticus, C. turicensis, C. muytjensii, C. dublinensis subsp. dublinensis, C. dublinensis subsp. lausannensis and C. dublinensis subsp. lactaridi (Iversen et al., 2008). In the present study, analysis of partial sequences of the $r p o B$ and $16 \mathrm{~S}$ rRNA genes showed that strain Ola $51^{\mathrm{T}}$ of group A is closely related to E. radicincitans $\mathrm{D} 5 / 23^{\mathrm{T}}$, with $100 \%$ bootstrap support. The low to moderate DNA-DNA relatedness with the type strains of $E$. radicincitans, $E$. cloacae and E. aerogenes and the differences in IS-PCR fingerprinting, SDS-PAGE of proteins, fatty acids and biological tests indicated that the strains of group A were distinct from currently defined Enterobacter species (Table 1). Based on these results and the current definition of bacterial species, we propose the classification of the novel diazotrophic bacteria of group A isolated from the wild rice species $O$. latifolia as members of Enterobacter oryzae sp. nov.

\section{Description of Enterobacter oryzae sp. nov.}

Enterobacter oryzae (o.ry'zae. L. gen. n. oryzae of rice, from which the first strains were isolated).

Cells are straight or slightly curved rods, $0.8-1.1 \times 1.4-$ $2.0 \mu \mathrm{m}$ (Supplementary Fig. S1). Gram-negative and motile. Facultatively anaerobic and chemo-organotrophic. Colonies on VM medium are circular, convex and translucent, with a diameter of $3 \mathrm{~mm}$ within 3 days at $28{ }^{\circ} \mathrm{C}$. Growth occurs at $10-40{ }^{\circ} \mathrm{C}$ (optimum $28-$ $37{ }^{\circ} \mathrm{C}$ ) and at $\mathrm{pH} 3.5-10 . \mathrm{NaCl}$ inhibits growth at concentrations above $5 \%$, but acetylene reduction activity is displayed at concentrations below $3 \%$. Resistant to erythromycin, neomycin and ampicillin $\left(300 \mu \mathrm{g} \mathrm{ml}{ }^{-1}\right)$, chloramphenicol $\left(50 \mu \mathrm{g} \mathrm{ml}^{-1}\right)$, streptomycin, tetracycline and gentamicin $\left(5 \mu \mathrm{g} \mathrm{ml}^{-1}\right)$, but not resistant to kanamycin $\left(5 \mu \mathrm{g} \mathrm{ml}^{-1}\right)$. Shows a positive reaction for lysine decarboxylase; negative for urease and reduction of nitrate to dinitrogen. Adonitol, L-aspartic acid, dulcitol, sodium oxalate, vanillic acid, sodium benzoate, sodium hippurate, $\mathrm{D}$-fructose, malate, mannitol, maltose and sorbitol can be used as sole carbon sources. The $\mathrm{G}+\mathrm{C}$ content of genomic DNA of the type strain is $55.0 \pm 0.4 \mathrm{~mol} \%$. According to $16 \mathrm{~S}$ rRNA gene sequence analysis, the closest phylogenetic relatives are $E$. radicincitans and E. cloacae.

Strain Ola $51^{\mathrm{T}}\left(=\mathrm{LMG} 24251^{\mathrm{T}}=\right.$ CGMCC $\left.1.7012^{\mathrm{T}}\right)$ is the type strain. The group A strains represented by strain Ola $51^{\mathrm{T}}$ were isolated as endophytic nitrogen-fixing bacteria from the wild rice species Oryza latifolia.

\section{Acknowledgements}

This work was supported by National Natural Science Foundation of China (NSFC; 30470002, 30770001), the Scientific Research Foundation for the Returned Overseas Chinese Scholars of the State Education Ministry (SRF for ROCS, SEM) and the Program for New Century Excellent Talents in University (NCET).

\section{References}

Baldani, V. L. D. \& Doebereiner, J. (1980). Host-plant specificity in the infection of cereals with Azospirillum spp. Soil Biol Biochem 12, 433-439.

Brenner, D. J., McWhorter, A. C., Kai, A., Steigerwalt, A. G. \& Farmer, J. J., III (1986). Enterobacter asburiae sp. nov., a new species found in clinical specimens, and reassignment of Erwinia dissolvens and Erwinia nimipressuralis to the genus Enterobacter as Enterobacter dissolvens comb. nov. and Enterobacter nimipressuralis comb. nov. J Clin Microbiol 23, 1114-1120.

Chaintreuil, C., Giraud, E., Prin, Y., Lorquin, J., Ba, A., Gillis, M., de Lajudie, P. \& Dreyfus, B. (2000). Photosynthetic bradyrhizobia are natural endophytes of the African wild rice Oryza breviligulata. Appl Environ Microbiol 66, 5437-5447.

Chen, W. X., Yan, G. H. \& Li, J. L. (1988). Numerical taxonomy study of fast-growing soybean rhizobia and proposal that Rhizobium fredii be assigned to Sinorhizobium gen. nov. Int J Syst Bacteriol 38, 392-397.

Cole, R. M. \& Popkin, T. J. (1981). Electron microscopy. In Manual of Methods for General Bacteriology, pp. 34-51. Edited by P. Gerhardt, R. G. E. Murray, R. N. Costilow, E. W. Nester, W. A. Wood, N. R. Krieg \& G. H. Phillips. Washington, DC: American Society for Microbiology.

De Ley, J., Cattoir, H. \& Reynaerts, A. (1970). The quantitative measurement of DNA hybridization from renaturation rates. Eur $J$ Biochem 12, 133-142.

Drancourt, M., Bollet, C., Carta, A. \& Rousselier, P. (2001). Phylogenetic analyses of Klebsiella species delineate Klebsiella and Raoultella gen. nov., with description of Raoultella ornithinolytica comb. nov., Raoultella terrigena comb. nov. and Raoultella planticola comb. nov. Int J Syst Evol Microbiol 51, 925-932.

Eckert, B., Weber, O. B., Kirchhof, G., Halbritter, A., Stoffels, M. \& Hartmann, A. (2001). Azospirillum doebereinerae sp. nov., a nitrogenfixing bacterium associated with the $\mathrm{C}_{4}$-grass Miscanthus. Int J Syst Evol Microbiol 51, 17-26.

Elbeltagy, A., Nishioka, K., Sato, T., Suzuki, H., Ye, B., Hamada, T., Isawa, T., Mitsui, H. \& Minamisawa, K. (2001). Endophytic colonization and in planta nitrogen fixation by a Herbaspirillum sp. isolated from wild rice species. Appl Environ Microbiol 67, 5285-5293.

Engelhard, M., Hurek, T. \& Reinhold-Hurek, B. (2000). Preferential occurrence of diazotrophic endophytes, Azoarcus spp., in wild rice species and land races of Oryza sativa in comparison with modern races. Environ Microbiol 2, 131-141.

Farmer, J. J., III, Davis, B. R., Hickman-Brenner, F. W., McWhorter, A., Huntley-Carter, G. P., Asbury, M. A., Riddle, C., Wathen-Grady, H. G., Elias, C. \& Fanning, G. R. (1985). Biochemical identification of new species and biogroups of Enterobacteriaceae isolated from clinical specimens. J Clin Microbiol 21, 46-76.

Fujie, T., Huang, Y. D., Higashitani, A., Nishimura, Y., Iyama, S., Hirota, Y., Yoneyama, Y. \& Dixon, R. A. (1987). Effect of inoculation with Klebsiella oxytoca and Enterobacter cloacae on dinitrogen fixation by rice-bacteria associations. Plant Soil 103, 221-226.

Gao, J. L., Sun, J. G., Li, Y., Wang, E. T. \& Chen, W. X. (1994). Numerical taxonomy and DNA relatedness of tropical rhizobia 
isolated from Hainan province of China. Int J Syst Bacteriol 44, 151158.

Hoffmann, H., Stindl, S., Ludwig, W., Stumpf, A., Mehlen, A., Heesemann, J., Monget, D., Schleifer, K. H. \& Roggenkamp, A. (2005a). Reassignment of Enterobacter dissolvens to Enterobacter cloacae as E. cloacae subspecies dissolvens comb. nov. and emended description of Enterobacter asburiae and Enterobacter kobei. Syst Appl Microbiol 28, 196-205.

Hoffmann, H., Stindl, S., Stumpf, A., Mehlen, A., Monget, D., Heesemann, J., Schleifer, K. H. \& Roggenkamp, A. (2005b). Description of Enterobacter ludwigii sp. nov., a novel Enterobacter species of clinical relevance. Syst Appl Microbiol 28, 206-212.

Hurek, T., Handley, L. L., Reinhold-Hurek, B. \& Piche, Y. (2002). Azoarcus grass endophytes contribute fixed nitrogen to the plant in an unculturable state. Mol Plant Microbe Interact 15, 233-242.

Iversen, C., Mullane, N., McCardell, B., Tall, B. D., Lehner, A., Fanning, S., Stephan, R. \& Joosten, H. (2008). Cronobacter gen. nov., a new genus to accommodate the biogroups of Enterobacter sakazakii, and proposal of Cronobacter sakazakii gen. nov., comb. nov., Cronobacter malonaticus sp. nov., Cronobacter turicensis sp. nov., Cronobacter muytjensii sp. nov., Cronobacter dublinensis sp. nov., Cronobacter genomospecies 1, and of three subspecies, Cronobacter dublinensis subsp. dublinensis subsp. nov., Cronobacter dublinensis subsp. lausannensis subsp. nov. and Cronobacter dublinensis subsp. lactaridi subsp. nov. Int J Syst Evol Microbiol 58, 1442-1447.

Kämpfer, P., Ruppel, S. \& Remus, R. (2005). Enterobacter radicincitans sp. nov., a plant growth promoting species of the family Enterobacteriaceae. Syst Appl Microbiol 28, 213-221.

Kosako, Y., Tamura, K., Sakazaki, R. \& Miki, K. (1996). Enterobacter kobei sp. nov., a new species of the family Enterobacteriaceae resembling Enterobacter cloacae. Curr Microbiol 33, 261-265.

Li, X., Zhang, D., Chen, F., Ma, J., Dong, Y. \& Zhang, L. (2004). Klebsiella singaporensis sp. nov., a novel isomaltulose-producing bacterium. Int J Syst Evol Microbiol 54, 2131-2136.

Marmur, J. (1961). A procedure for the isolation of deoxyribonucleic acid from microorganisms. J Mol Biol 3, 208-218.

Mollet, C., Drancourt, M. \& Raoult, D. (1997). rpoB sequence analysis as a novel basis for bacterial identification. Mol Microbiol 26, 1005-1011.

Nicholas, K. B. \& Nicholas, H. B., Jr (1997). GeneDoc: a tool for editing and annotating multiple sequence alignments. http://www.nrbsc.org/ downloads/

O'Hara, C. M., Steigerwalt, A. G., Hill, B. C., Farmer, J. J., III, Fanning, G. R. \& Brenner, D. J. (1989). Enterobacter hormaechei, a new species of the family Enterobacteriaceae formerly known as enteric group 75 . J Clin Microbiol 27, 2046-2049.

Pavan, M. E., Franco, R. J., Rodriguez, J. M., Gadaleta, P., Abbott, S. L., Janda, J. M. \& Zorzópulos, J. (2005). Phylogenetic relationships of the genus Kluyvera: transfer of Enterobacter intermedius Izard et al. 1980 to the genus Kluyvera as Kluyvera intermedia comb. nov. and reclassification of Kluyvera cochleae as a later synonym of K. intermedia. Int J Syst Evol Microbiol 55, 437-442.

Peng, G., Wang, H., Zhang, G., Hou, W., Liu, Y., Wang, E. T. \& Tan, Z. (2006). Azospirillum melinis sp. nov., a group of diazotrophs isolated from tropical molasses grass. Int J Syst Evol Microbiol 56, 1263-1271.

Reinhold-Hurek, B., Hurek, T., Gillis, M., Hoste, B., Vancanneyt, M., Kersters, K. \& De Ley, J. (1993). Azoarcus gen. nov., nitrogen-fixing proteobacteria associated with roots of Kallar grass (Leptochloa fusca (L.) Kunth), and description of two species, Azoarcus indigens sp. nov. and Azoarcus communis sp. nov. Int J Syst Bacteriol 43, 574-584.

Saitou, N. \& Nei, M. (1987). The neighbor-joining method: a new method for reconstructing phylogenetic trees. Mol Biol Evol 4, 406425 .

Sasser, M. (1990). Identification of bacteria by gas chromatography of cellular fatty acids. MIDI Technical Note 101. Newark, DE: Microbial ID, Inc.

Sneath, P. H. A. \& Sokal, R. R. (1973). Numerical Taxonomy. The Principles and Practice of Numerical Classification. San Francisco: W. H. Freeman.

Stephan, R., Van Trappen, S., Cleenwerck, I., Vancanneyt, M., De Vos, P. \& Lehner, A. (2007). Enterobacter turicensis sp. nov. and Enterobacter helveticus sp. nov., isolated from fruit powder. Int J Syst Evol Microbiol 57, 820-826.

Tan, Z. Y., Wang, E. T., Peng, G. X., Zhu, M. E., Martínez-Romero, E. \& Chen, W. X. (1999). Characterization of bacteria isolated from wild legumes in the north-western regions of China. Int J Syst Bacteriol 49, 1457-1469.

Tan, Z., Hurek, T., Gyaneshwar, P., Ladha, J. K. \& Reinhold-Hurek, B. (2001). Novel endophytes of rice form a taxonomically distinct subgroup of Serratia marcescens. Syst Appl Microbiol 24, 245-251.

Thompson, J. D., Higgins, D. G. \& Gibson, T. J. (1994). CLUSTAL W: improving the sensitivity of progressive multiple sequence alignment through sequence weighting, position-specific gap penalties and weight matrix choice. Nucleic Acids Res 22, 4673-4680.

Tou, C. \& Zhou, F. (1989). Non-nodular endorhizospheric nitrogen fixation in wetland rice. Can J Microbiol 35, 403-408.

Ueda, T., Suga, Y., Yahiro, N. \& Matsuguchi, T. (1995). Remarkable $\mathrm{N}_{2}$-fixing bacterial diversity detected in rice roots by molecular evolutionary analysis of nifH gene sequences. J Bacteriol 177, 14141417.

Van de Peer, Y. \& De Wachter, R. (1994). TREECON for Windows: a software package for the construction and drawing of evolutionary trees for the Microsoft Windows environment. Comput Appl Biosci 10, 569-570.

Vaughan, D. A. (1989). The genus Oryza L. Current status of taxonomy. Manila IRRI Res Pap Ser 138, 9. 